\title{
Technical and economic aspects of the use of microwave technologies in crop production
}

\author{
Andrey Bastron ${ }^{1}$, Tatiana Bastron ${ }^{1}$, Irina Ermakova ${ }^{1}$, Natalia Mikheeva $^{1,{ }^{*}}$ and Irina \\ Yamshchikova $^{2}$ \\ ${ }^{1}$ Krasnoyarsk State Agrarian University, Prospekt Mira, 90, 660049 Krasnoyarsk, Russia \\ ${ }^{2}$ Irkutsk National Research Technical University, Lermontov street, 83, 664074 Irkutsk, Russia
}

\begin{abstract}
Ensuring food security is achieved by increasing the volume of agricultural products in compliance with environmental requirements. The proposed technologies for pre-sowing treatment of rapeseed seeds with EMF UHF will improve the quality of these seeds, which, ultimately, will affect the increase in yield, as well as provide gain in yield and improve the quality of oil during processing. The implementation of the project of pre-sowing treatment of rapeseed seeds with EMF UHF in this regard, for example, in LLC "Nichkinskoe" of the Minusinsky District, seems promising. The article devoted to the economic assessment of two possible technologies for pre-sowing treatment of seeds with EMF UHF in LLC "Nichkinskoe" of the Minusinsky District with the use of spring rapeseed varieties "Nadezhny-92" and "Hephaestus". It is established that additional income can be obtained for both options.
\end{abstract}

\section{Introduction}

Food security is interconnected with all types of national security of the State. The Russian Federation has approved the Food Security Doctrine [1]. Food security is a state of socio-economic development that, firstly, ensures the country's food independence, and secondly, guarantees physical and economic accessibility to food products for every citizen of the Russian Federation.

Small grains are the basis of food security. Food independence is understood as the level of self-sufficiency in products, which is considered as the ratio of production and domestic consumption of domestic agricultural products, raw materials and food. The assessment of this level is made according to the threshold indicators of this criterion for specific types of products. According to the Doctrine, the value of this indicator for grain is at least $95 \%$. It is obvious that the need to increase grain production is urgent, taking into account not only domestic consumption, but also significant export potential, as well as current global environmental requirements for environmental protection and the production of environmentally friendly products. Proposals for the use of microwave technology in the crop production industry is one of the most relevant ways to solve these problems.

\footnotetext{
*Corresponding author: balabon08@mail.ru
} 


\section{Materials and Methods}

Technologies of microwave pre-sowing seed treatment can be used to treat seeds of various agricultural crops. A significant economic effect can be obtained by microwave processing of feed crop seeds, which will improve the state of the feed base in animal husbandry and, as a result, increase the productivity of farm animals. If the threshold indicator for meat and meat products is at least $85 \%$, and for milk and dairy products is at least $90 \%$, an increase in these indicators will be achieved.

The purchase of a microwave in a specific enterprise will allow processing seeds of various crops not only for their own needs, but also provide processing services for other enterprises. This service will not cause difficulties, because the volumes of processed seed material are relatively small. The use of processed seeds will provide an increase in yield and the overall effect by increasing the yield of agricultural crops in the region.

It is also necessary to note the social effect of seed processing for the rural population, which will be achieved by obtaining additional products and increasing income from personal household farms, this service can also be used by farmers.

It is important to note that the microwave technologies of pre-sowing seed treatment meet environmental requirements by reducing the area of crops to produce the same volume of products, reducing part of the costs of fertilizers and pesticides, the amount of fuel, as well as replacing the technology of seed etching during their pre-sowing treatment with environmentally friendly microwave technologies.

The climatic conditions of Eastern Siberia are such that periods with low temperatures occur during the ripening of seeds, because of which they become physiologically immature and susceptible to all kinds of diseases. In this case, pre-sowing treatment of seeds is firstly necessary to increase their germination and germination energy, and, if necessary, for disinfection, which ultimately affects the increase in plant productivity and, accordingly, yield [2-11].

The conducted scientific research of various scientific and educational institutions of Russia (RESCH, BGSHA, YUrGAU, Irkutsk State Agrarian University, Krasnoyarsk State Agrarian University, etc.) and other countries has proved that the electrotechnological methods of pre-sowing of seeds of various agricultural crops are not inferior to traditional ones [2-12].

Reducing the contamination of seeds of agricultural crops from infections, improving their growth qualities (increasing germination and germination energy, obtaining an earlier harvest) and, ultimately, increasing yields, can be achieved by using technologies developed in Krasnoyarsk State Agrarian University with the use of rational modes of presowing treatment with ultrahigh frequency electromagnetic fields (EMF UHF) [4-8, 10$11]$.

According to the above, obtaining seed with improved sowing quality indicators with minimal energy consumption is relevant in relation to the justification of technologies for pre-sowing treatment of rapeseed in LLC "Nichkinskoe" of the Minusinsky District.

The productivity of the microwave technologies developed on Krasnoyarsk State Agrarian University on the basis of a microwave $[4,5]$ is approximately $35 \mathrm{~kg} / \mathrm{h}$ (fig. 1). 


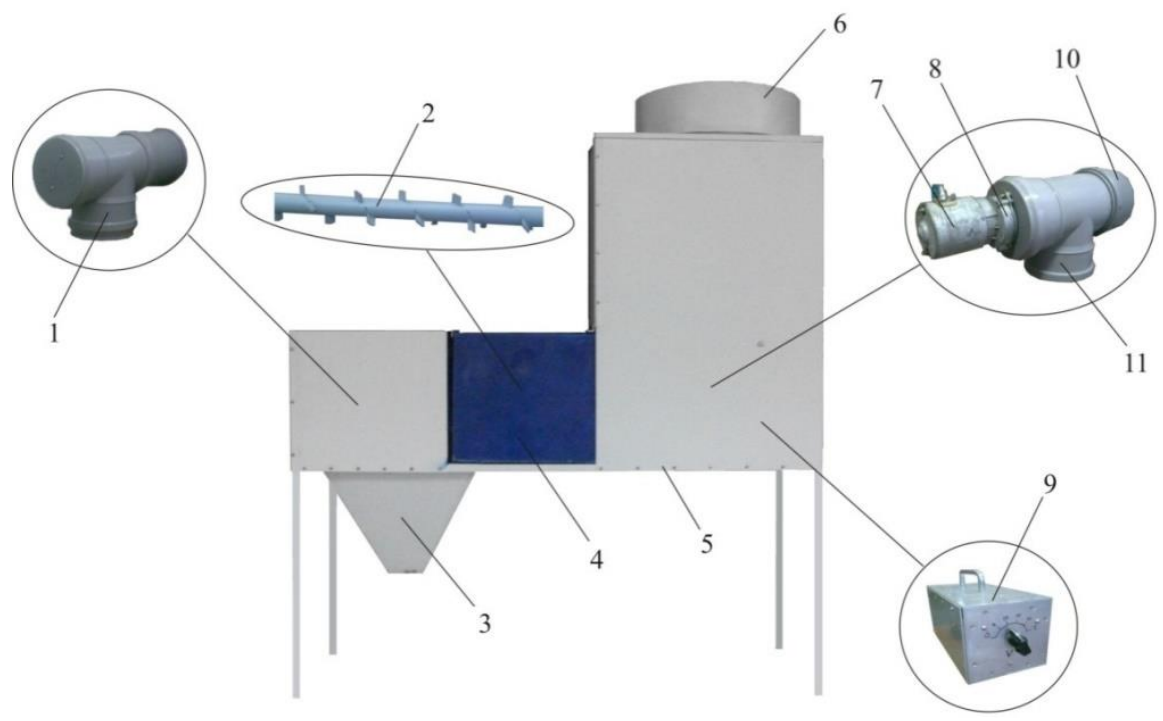

Fig. 1. Experimental microwave for microwave processing of bulk dielectric materials: 1 - discharge hole; 2 - screw; 3 - hopper; 4 - working chamber; 5 - frame; 6 - storage hopper; 7 electric drive of the auger; 8 - gearbox; 9 - transformer; 10 - casing; 11 - loading hole

The seed material is spring rapeseed, the breed is "Nadezhny-92" (elite seeds) of Siberian selection. Taking the average sown area sown by LLC "Nichkinskoe" for rapeseed equal to 1,500 hectares (in fact, approximately 1,500 ha were sown in 2020), the need for seeds will be $6,750 \mathrm{~kg}$ with a seeding rate of rapeseed seeds of linear varieties from 4 to $5 \mathrm{~kg} / \mathrm{ha}$ (we take an average of $4.5 \mathrm{~kg} / \mathrm{ha}$ ), we will determine the required operating time of the microwave. It will take 193 hours or approximately 12 shifts. If we carry out pre-sowing microwave treatment of seeds ahead of time, and then sow for 5 days, the increased germination and disinfecting effect will not be lost. According to LLC "Nichkinskoe", the sowing campaign of rapeseed in 2020 lasted approximately 7 days.

However, in 2021, LLC "Nichkinskoe" plans to increase the sown area of rapeseed twice, which will be about 3,000 hectares. It is supposed to use the following seed material — the imported spring rapeseed "Hephaestus" (elite seeds). The need for seeds will be $10,500 \mathrm{~kg}$. Thus, the performance of the microwave developed by Krasnoyarsk State Agrarian University will not be enough, and therefore the microwave for microwave processing and drying of bulk products UMOS-02 was chosen, which was developed on the basis of the Federal State Budgetary Scientific Institution "All-Russian Research Institute of Radiology and Agroecology" and manufactured at the enterprise of LLC Research and Production Enterprise "Agroecotech" in Obninsk (Fig. 2) [9]. 




Fig. 2. Microwave UMOS-02 for processing and drying of bulk products

A detailed description of the principle of operation of the Microwave UMOS-02 and its technical information are given in [9].

Taking the sown area of 3,000 ha, with a seeding rate of rapeseed of hybrid varieties of about $3.5 \mathrm{~kg}$ per $1 \mathrm{ha}$, we get the required seed weight for pre-sowing treatment of EMF UHF - approximately 10.5 tons. Considering that the productivity of the UMOS-02 (approximately $300 \mathrm{~kg} / \mathrm{h}$ ) with continuous one-shift operation, pre-sowing treatment of rapeseed with EMF UHF can be performed in five days (2.1 tons per day).

The use of the new technology instead of the old one is justified if it is accompanied with an increase of economic indicators [14].

In order to calculate economic indicators and assess economic efficiency, it is proposed to compare two options for the cultivation of oilseeds (rapeseed) that differ in quality of the seed material, using the example of growing spring rapeseed in LLC "Nichkinskoe" of the Minusinsky district (Table 1).

Option 1.

The sown area of sawing spring rapeseed in LLC "Nichkinskoe" in 2020 was 1,500 ha. For pre-sowing seed treatment, we will take for calculation an installation developed at the Department of Power Supply of Agriculture of Krasnoyarsk State Agrarian University with an installed capacity of $2.5 \mathrm{~kW}$ [1]. The processing time of the seed material will be 193 hours, with the installation capacity of $35 \mathrm{~kg} / \mathrm{h}$. The seed material is spring rapeseed "Nadezhny-92" (elite seeds) of Siberian selection. The need for seeds will be $6,750 \mathrm{~kg}$.

Option 2.

In 2021, it is planned to increase the sown area of spring rapeseed of LLC "Nichkinskoe" to 3,000 ha. For pre-sowing seed treatment, we will take for calculation UMOS02, which was developed on the basis of the Federal State Funded Research Institution "All-Russian Scientific Research Institute of Radiology and Agroecology" and manufactured at the enterprise of LLC Research and Production Enterprise "Agroecotech". With the installed capacity of $3.0 \mathrm{~kW}$. The processing time of the seed material will be 35 hours, with the installation capacity of up to $300 \mathrm{~kg} / \mathrm{h}$. The seed material is spring rapeseed "Hephaestus" (elite seeds) of the import production. The need for seeds will be $10,500 \mathrm{~kg}$.

According to laboratory and field studies conducted at the Department of Power Supply of Agriculture of the Federal State Educational Institution of the Russian Academy of Sciences of A. A. Vasilenko, during pre-sowing treatment of brewing barley seeds with EMF 
UHF, the yield increase was up to $17.6 \%$ [11].

Taking into account the data of laboratory and field studies, we assume an increase in the yield of spring rapeseed by at least $10 \%$, therefore, according to option No. 1, with a gross harvest of 3,000 tons, the increase in yield will be 300 tons.

The expected yield of spring rapeseed seeds according to option No. 2 with a sown area of 3,000 ha will be 12,000 tons, respectively, the increase in yield will be 1,200 tons.

Table 1. Characteristics of the compared options

\begin{tabular}{|l|l|c|c|}
\hline $\begin{array}{l}\text { Item } \\
\text { No. }\end{array}$ & Name of indicators & Option 1 & Option 2 \\
\hline 1 & Sown area, ha & 1,500 & 3,000 \\
\hline 2 & Need for seed material, tons & 6,750 & 10,500 \\
\hline 3 & Operating time of the installation, hour & 193 & 35 \\
\hline 4 & Number of installations, pcs & 1 & 1 \\
\hline 5 & Installation capacity, $\mathrm{kW}$ & 2.5 & 3.0 \\
\hline 6 & Energy consumption, $\mathrm{kW} / \mathrm{h}$ & 482.5 & 105 \\
\hline 7 & Breed of seeds & "Linear" & "Hybride" \\
\hline & Yield, $\mathrm{t} / \mathrm{ha}$ & 2 & 4 \\
\hline
\end{tabular}

\section{Results and Discussion}

The calculation of the economic efficiency of pre-sowing treatment of rapeseed seeds with EMF UHF was carried out according to the method described in $[14,15]$. The initial data are given in Table 2, the results of the calculations are given in Table 3.

Table 2. The initial data and results of calculating the amount of income received through the implementation of the project

\begin{tabular}{|l|l|c|c|}
\hline $\begin{array}{l}\text { Item } \\
\text { No. }\end{array}$ & Name of indicators & Option 1 & Option 2 \\
\hline 1 & $\begin{array}{l}\text { Gross harvest of grain without microwave processing, } \\
\text { tons }\end{array}$ & 3,000 & 12,000 \\
\hline 2 & $\begin{array}{l}\text { Additional products obtained through microwave treat- } \\
\text { ment of seeds, tons }\end{array}$ & 300 & 1,200 \\
\hline 3 & Sale price of rapeseed seeds, thousand rubles/t & 32 & 38 \\
\hline 4 & Gross harvest of rapeseed under the project, tons & 3,300 & 13,200 \\
\hline 5 & Additional income (result), thousand rubles & 9,600 & 45,600 \\
\hline
\end{tabular}

Table 3. Main technical and economic indicators for the project

\begin{tabular}{|l|l|c|c|}
\hline $\begin{array}{l}\text { Item } \\
\text { No. }\end{array}$ & Name of indicators & Option 1 & Option 2 \\
\hline 1 & Type of the installed equipment. & $\begin{array}{c}\text { Microwave devel- } \\
\text { oped by Krasno- } \\
\text { yarsk State Agrari- } \\
\text { an University }\end{array}$ & $\begin{array}{c}\text { Microwave } \\
\text { UMOS-02 }\end{array}$ \\
\hline & - the installed capacity, $\mathrm{kW}$ & 2.5 & 3.0 \\
\hline & - energy consumption, $\mathrm{kW} / \mathrm{h}$ & 482.5 & 105 \\
\hline & - operating time of the installation, hour & 193 & 35 \\
\hline 2 & $\begin{array}{l}\text { Gross harvest of rapeseed under the project, } \\
\text { tons }\end{array}$ & 3,300 & 13,200 \\
\hline 3 & Outlays, thousand rubles & 96.8 & 435 \\
\hline 4 & Annual operating costs, thousand rubles/year & 429 & 18,486 \\
\hline & - electricity costs, thousand rubles. & 3.76 & 0.82 \\
\hline & - wages, thousand rubles & 11.9 & 4.9 \\
\hline
\end{tabular}


Table 3. Continued

\begin{tabular}{|l|l|c|c|}
\hline & - amortization, thousand rubles & 12.1 & 54.4 \\
\hline & $\begin{array}{l}\text { - costs for the purchase of seeds, thousand ru- } \\
\text { bles }\end{array}$ & 405 & 9,450 \\
\hline & $\begin{array}{l}\text { - additional costs associated with an increase in } \\
\text { the sown area, thousand rubles }\end{array}$ & - & 9,000 \\
\hline 5 & $\begin{array}{l}\text { Additional income (result) due to the sale of } \\
\text { additional products, thousand rubles }\end{array}$ & 9,600 & 45,600 \\
\hline 6 & $\begin{array}{l}\text { Net discounted income (result) for three years, } \\
\text { thousand rubles }\end{array}$ & 17,499 & 74,795 \\
\hline & - including for the 1st year, thousand rubles & 5,833 & 24,932 \\
\hline
\end{tabular}

\section{Conclusions}

1. The use of microwave technologies to increase crop yields meets the requirements of the Food Security Doctrine and ensures the production of environmentally friendly products.

2. The economic efficiency of the use of microwave technologies for pre-sowing treatment of rape seeds has been proved.

3. The net discounted income for three years under option No. 2 using UMOS-02, which was developed on the basis of the Federal State Funded Research Institution "All-Russian Scientific Research Institute of Radiology and Agroecology" and manufactured at the enterprise of LLC Research and Production Enterprise "Agroecotech", is significantly higher. It is obvious that option No. 2 is economically effective and can be recommended for implementation for use on farms over 1,500 ha of sown areas.

4. Moreover, when introducing a microwave at agricultural enterprises, it can be used for pre-sowing treatment of seeds of other agricultural crops, which will provide additional income while reducing sown areas.

\section{References}

1. Food Security Doctrine of the Russian Federation (Approved by the Decree of the President of the Russian Federation dated January 21, 2020 No. 20), https://mcx.gov.ru/

2. V.A. Fedotov, Bulletin of the Agroindustrial Complex of Stavropol, 3 (15), 52 (2014)

3. V.A. Fedotov, Innovations in agriculture, 5 (15), 70 (2015)

4. A.V. Bastron, Bulletin of Krasnoyarsk State Agrarian University, 5 (104), 63 (2015)

5. A.V. Bastron, Rural machine operator, 4, 16 (2017)

6. A.V. Isayev, Bulletin of Krasnoyarsk State Agrarian University, 9 (108), 155 (2015)

7. M.V. Gorelov, IOP Conference Series: Earth and Environmental Science. Krasnoyarsk Science and Technology City Hall of the Russian Union of Scientific and Engineering Associations, 52069 (2019)

8. A.A. Vasilenko, Bulletin of Orenburg State Agrarian University, 6 (80), 169 (2019)

9. Installation UMOS-02 for microwave processing and drying of bulk products, https://www.rirae.ru/

10. A.V. Bastron, IOP Conference Series: Earth and Environmental Science. Conference proceedings. Krasnoyarsk Science and Technology City Hall of the Russian Union of Scientific and Engineering Associations, 22065 (2020) 
11. A. V. Vasilenko, Justification of the modes of disinfection of malting barley seeds with EMF UHF energy, 114 (2015)

12. N.D. Polevik, Bulletin of Kransoyarsk State Agrarian University, 8 (59), 223 (2011)

13. E.P. Kondratenko, Agrarian Russia, 4, 18 (2016)

14. A.V. Isayev, Bulletin of Irkutsk State Agrarian University, 73, 125 (2016)

15. Methodological recommendations for evaluating the effectiveness of investment projects (second edition). Official edition. (2000) 